Background: Sodium nitroprusside (SNP) and molsidomine are used in the treatment of coronary heart disease. Since the neutrophils play a pathological role in ischaemic heart disease, it is important to understand the direct action of nitrovasodilators on their function.

Aim: We examined the effects of SNP and 3-morpholinosydnonimine (SIN-1, molsidomine metabolite) on the respiratory burst of human neutrophils and their adhesion in vitro. The influence of nitric oxide (NO) donors on the activity of protein kinases, which are involved in the NADPH oxidase activation, was also investigated.

Methods: The respiratory burst of neutrophils was determined by chemiluminescence and fluorescence methods, while the adhesion was assayed by adherence of neutrophils to the plastic surface.

Results: NO donors decreased the oxidative burst of activated neutrophils. However, the effects of SNP and SIN-1 strongly depended on the treatment time of neutrophils and on the stimulus employed to cells activation. Protein kinase $C$ inhibitor did not prevent the inhibitory effect of SIN-1, but diminished the inhibitory effect of SNP on the neutrophils' respiratory burst. Protein tyrosine kinase inhibitor did not affect the action of SNP, but diminished the inhibitory effect of SIN-1 on fMLP-stimulated but not on PMAstimulated oxidative burst of neutrophils. This suggests that SNP action is mainly associated with protein kinase $C$, while SIN-1 is associated with protein tyrosine kinase activity. We also found that SIN-1 but not SNP diminished the adhesive activity of neutrophils.

Conclusions: Our data show that SIN-1 biological effect on some neutrophils activity is different from both spermine NONOate and SNP, and mainly depends on $\mathrm{ONOO}^{-}$, while SNP action is mediated by NO.

Key words: Nitrovasodilators, Neutrophils, Respiratory burst, Protein kinases, Adherence

\section{Oxidative and adhesive responses of human neutrophils to nitrovasodilators in vitro: the role of protein kinases}

\author{
Magdalena Klink ${ }^{1, C A}$, Henryk Tchorzewski ${ }^{1,2}$ and \\ Zofia Sulowska'
}

${ }^{1}$ Microbiology and Virology Centre, Polish Academy of Sciences, Lodowa 106, 93-232 Lodz, Poland; and ${ }^{2}$ Department of Clinical Immunology, Institute of Polish Mother's Memorial Hospital, Lodz, Poland

\author{
${ }^{\mathrm{CA}}$ Corresponding author \\ Tel: +48426771236 \\ Fax +48426771230 \\ E-mail: MKlink@poczta.onet.pl
}

\section{Introduction}

Neutrophils play a key role in the pathogenesis of ischaemic heart disease as the mediators of myocardial ischaemia reperfusion injury. Activated neutrophils produce and release a variety of powerful inflammatory mediators such as reactive oxygen species, enzymes and cytokines that are responsible for cell and tissue damage and serious complications associated with heart diseases. ${ }^{1-3}$

The reactive oxygen species are produced by neutrophils as result of NADPH oxidase activation (reactions named 'respiratory burst'). Various protein kinases are involved in the NADPH oxidase activation including protein kinase $\mathrm{C}$ (PKC), mitogen-activated protein kinases, protein kinase $\mathrm{A}$, and protein tyrosine kinase (PKT). ${ }^{4-10}$ NADPH oxidase can be activated by various stimuli such as chemotactic peptide (formylo-methionylo-leucylo-phenylalanine (fMLP)), phorbol 12-myristate 13-acetate (PMA) or opsonized zymosan. Stimulation of neutrophils with fMLP, a receptor-dependent stimulator, activates Gproteins and various downstream proteins including PKC, PKT, and mitogen-activated protein kinase. PMA as a receptor-independent stimulator directly activates PKC without G-proteins participation. It also indirectly activates mitogen-activated protein kinase and probably PKT. ${ }^{6,9-11}$

Nitric oxide (NO) donors such as sodium nitroprusside (SNP) and molsidomine are used as nitrovasodilators in the treatment of patients with coronary heart disease. ${ }^{12-14}$ Besides their effects on the vascular smooth muscle cells, NO-releasing compounds may affect the circulating white blood 
cells; for example, inhibit the adhesion, aggregation and chemotaxis of neutrophils. ${ }^{15}$

The recognition of the pathway by which the nitrovasodilators affect neutrophils function seems to be significant. The aim of this study was to examine the effects of SNP and 3-morpholinosydnonimine (SIN-1, molsidomine metabolite) on the respiratory burst of human neutrophils and their adhesion in vitro. The influence of these compounds on the activity of kinases (PKT and PKC) that are involved in the NADPH oxidase activation was investigated.

\section{Materials and methods}

\section{Chemical reagents}

Polymorphprep was obtained from Nycomed (Oslo, Norway). Hanks' balanced salt solution (HBSS), SNP, SIN-1, PMA, spermine NONOate, genistein, herbimicin A, 1-(5-isoquinolinylsulfonyl)-2methylpiperazine (H-7), NPC 15437, fMLP, tumour necrosis factor-alpha (TNF- $\alpha$ ), human recombinant, $2^{\prime}, 7^{\prime}$-dichlorofluorescein (DCFH) diacetate, 3-[4.5-dimethylthiazol-2-yl]-2.3-diphenyltetrazolium bromide (MTT), sodium nitrite, sulfanilamide, naphthylethylenediamine dihydrochloride, and phosphoric acid were purchased from Sigma (USA). Luminol was a product of Serva (Germany). Phosphate-buffered saline (PBS) was purchased from BIOMED-Lublin (Poland).

\section{Isolation of neutrophils}

Heparinized peripheral blood was obtained from healthy volunteers and the neutrophils were isolated by centrifugation of blood sample on Polymorphprep as described previously. ${ }^{16}$ The Regional Commission approved the protocol of these studies for Ethics in Research.

\section{Measurement of the generation of nitric oxide from NO donor compounds}

NO donors $(10-1000 \mu \mathrm{M})$ were added to HBSS (cell free system) or to neutrophils $\left(1 \times 10^{5}\right.$ cells $)$ in HBSS for 30 or $60 \mathrm{~min}$ at $37^{\circ} \mathrm{C}$. The generation of $\mathrm{NO}$ was measured using Griess reagent as described previously. $^{16}$

\section{Respiratory burst of neutrophils}

Two assays were used to assess the respiratory burst because a single technique could be insufficient to determine the effect of different NO donors on the neutrophil function. ${ }^{16}$ Luminol-enhanced chemiluminescence measures the intracellularly and extracellu- larly released NADPH-derived and myeloperoxidasederived oxygen metabolites, while DCFH oxidation assay measures the NADPH-derived oxygen species generated mainly intracellularly. ${ }^{17,18}$

Chemiluminescence (CL) was measured in a 96well plate Fluoroscan Ascent FL fluorometer (Labsystem, Helsinki, Finland). Neutrophils $\left(1 \times 10^{5}\right.$ cells/ well in HBSS) were untreated or pre-treated with 1 , 10,100 or $1000 \mu \mathrm{M}$ of SNP or SIN-1 for $1-2$ min or 30 min at $37^{\circ} \mathrm{C}$ with $5 \% \mathrm{CO}_{2}$ as indicated in the figures. In control experiments, the neutrophils were pretreated with $10 \mu \mathrm{M}$ or $100 \mu \mathrm{M}$ of spermine NONOate for $1-2 \mathrm{~min}$ or $30 \mathrm{~min}$ at $37^{\circ} \mathrm{C}$ with $5 \% \mathrm{CO}_{2}$. PMA $(0.1$ $\mu \mathrm{g} / \mathrm{ml})$ or fMLP $\left(10^{-6} \mathrm{M}\right)$ to initiate the respiratory burst and luminol $\left(10^{-5} \mathrm{M}\right)$ to enhance $\mathrm{CL}$ were added to the cells. In some experiments the neutrophils were pre-treated with $100 \mu \mathrm{M}$ or $1000 \mu \mathrm{M}$ of SNP or SIN-1 for $30 \mathrm{~min}$ at $37^{\circ} \mathrm{C}$ with $5 \% \mathrm{CO}_{2}$, and $\mathrm{NO}$ donors were then removed. PMA, fMLP and luminol were then added as previously. The CL reading for all experiments was recorded for $30 \mathrm{~min}$ at $2 \mathrm{~min}$ intervals. The CL intensity was given in relative light units (RLU). The data were expressed as the area under the curve of CL versus time (RLU total).

The DCFH oxidation assay was measured in a 96well plate Fluoroscan Ascent FL fluorometer (Labsystem). Briefly, the neutrophils $\left(2 \times 10^{6}\right.$ cells $\left./ \mathrm{ml}\right)$ were loaded with DCFH diacetate $(100 \mu \mathrm{g} / \mathrm{ml})$ in HBSS for $30 \mathrm{~min}$ at $37^{\circ} \mathrm{C}$, with $5 \% \mathrm{CO}_{2}$. Cells were then washed twice with PBS, resuspended in fresh HBSS and distributed into a 96-well plate $\left(1 \times 10^{5}\right.$ cells/well). Neutrophils were untreated or pre-treated with SNP or SIN-1 at concentrations of $1,10,100$ or $1000 \mu \mathrm{M}$ for $1-2 \mathrm{~min}$ or $30 \mathrm{~min}$ at $37^{\circ} \mathrm{C}$ with $5 \% \mathrm{CO}_{2}$. The plate was placed into fluorometer and the intensity of fluorescence was determined at $485 \mathrm{~nm}$ excitation and $530 \mathrm{~nm}$ emission wavelengths $\left(T_{0}\right)$. Neutrophils were then stimulated with PMA $(0.1 \mu \mathrm{g} / \mathrm{ml})$ or fMLP $\left(10^{-6} \mathrm{M}\right)$ for the next $30 \mathrm{~min}$ at $37^{\circ} \mathrm{C}$ with $5 \% \mathrm{CO}_{2}$. After that time, the intensity of fluorescence was measured once more as described earlier $\left(T_{30}\right)$. In some experiments the neutrophils were untreated or pre-treated with $100 \mu \mathrm{M}$ or $1000 \mu \mathrm{M}$ of SNP or SIN-1 for $30 \mathrm{~min}$ at $37^{\circ} \mathrm{C}$ with $5 \% \mathrm{CO}_{2}$. Cells were then washed to remove NO-releasing drugs. The intensity of fluorescence at $T_{0}$ and after stimulation with PMA or fMLP at $T_{30}$ was measured. The percentage of increase in the intensity of fluorescence was calculated from the formula $\left.\left[\left(\mathrm{FT}_{30}-\mathrm{FT}_{0}\right) / \mathrm{FT}_{0}\right)\right] \times 100 .{ }^{19}$

\section{Determination of the role of PKT and PKC activity in the NO donor-mediated respiratory burst}

Neutrophils $\left(1 \times 10^{5}\right.$ cells/well $)$ were pre-treated with PKT inhibitors genistein $(10 \mu \mathrm{M})$ and herbimicin A $(1 \mu \mathrm{M})$ or PKC inhibitors H-7 $(100 \mu \mathrm{M})$ and NPC (1 $\mu \mathrm{M})$ for $15 \mathrm{~min}$ at $37^{\circ} \mathrm{C}$ with $5 \% \mathrm{CO}_{2}$. Neutrophils 
were then incubated with SNP or SIN-1 (100 $\mu \mathrm{M}$ and $1000 \mu \mathrm{M})$ or with NONOate $(10 \mu \mathrm{M}$ and $100 \mu \mathrm{M})$ for 30 min. PMA, fMLP and luminol were then added as already described. The data were expressed as the mediated by NO donors' per cent inhibition of PMAinduced or fMLP-induced respiratory burst of neutrophils calculated by the following formulae:

A. $\quad\left[\left(R_{L} U_{\text {total }}\right.\right.$ of cells treated with SNP or SIN + stimulated with PMA or fMLP $)-\left(\right.$ RLU $_{\text {total }}$ of cells treated with SNP or SIN-1)/(RLU total of cells stimulated with PMA or fMLP) - $\left(\mathrm{RLU}_{\text {total }}\right.$ of untreated (control) cells)] $\times$ $100 \%$

B. $\left[\left(\mathrm{RLU}_{\text {total }}\right.\right.$ of cells pretreated with PKC or PKT inhibitor and SNP or SIN-1 + stimulated with PMA or fMLP $)-\left(R_{L} U_{\text {total }}\right.$ of cells treated with SNP or SIN-1+ stimulated with PKC or $\mathrm{PKT}) /\left(\mathrm{RLU}_{\text {total }}\right.$ of cells treated with PKC or PKT inhibitor + stimulated with PMA or fMLP) - $\left(R_{L} U_{\text {total }}\right.$ of cells treated with PKC or PKT inhibitor)] $\times 100 \%$.

\section{Measurement of neutrophil adhesion}

The adhesion was assayed by adherence of neutrophils to the plastic surface. This is a simple quantitative technique to examine the ability of human neutrophils to active adherence in vitro. ${ }^{20}$ Briefly, neutrophils were treated with SNP and SIN-1 or with $20 \mathrm{ng} / \mathrm{ml}$ of TNF- $\alpha$ (as indicated later in Table 2). Non-adherent cells were removed by carefully washing the wells' surface with PBS and adherent neutrophils were exposed to MTT (2 $\mathrm{mg} / \mathrm{ml}$ of PBS) containing $10 \mathrm{ng} / \mathrm{ml}$ of PMA for $30 \mathrm{~min}$. Formazan produced by adherent cells was dissolved in $500 \mu \mathrm{l}$ of 2-propanol. The absorbance at $560 \mathrm{~nm}$ and $630 \mathrm{~nm}$ dual wavelength was measured in an ELISA reader Multiscan RC (Labsystem). The absorption of formazan is directly related to the number of adherent neutrophils. ${ }^{20}$ The amount of adherent cells was also controlled microscopically by independent re- searcher. The loss of cells treated with SIN-1 was observed under the microscope.

\section{Statistical analysis}

Data are presented as the mean \pm standard deviation. Statistical analysis was performed with Wilcoxon's singed rank test. Statistical significance was defined as $p \leq 0.05$.

\section{Results}

\section{Oxidative response of neutrophils to nitrovasodilators}

The generation of nitrite (a stable metabolite of NO) from NO donors in the presence of neutrophils or in the cell free system is presented in Table 1.

In pilot experiments, we noticed that $1 \mathrm{~min}$ or 30 min pre-treatment of neutrophils with SNP or SIN-1 at $1 \mu \mathrm{M}$ and $10 \mu \mathrm{M}$ had no significant effects on oxygen radical generation by stimulated cells (data not shown). Therefore, the concentrations of $100 \mu \mathrm{M}$ and $1000 \mu \mathrm{M}$ were selected for further experiments.

We observed that $1-2$ min pre-incubation with either SNP or SIN-1 decreased the respiratory burst of PMA-stimulated neutrophils as it was measured with CL and DCFH oxidation assays. The effect of preincubation with SNP and SIN-1 on the respiratory burst of fMLP-stimulated neutrophils was not seen when CL measurement was used. However, different effects of SNP and SIN-1 on fMLP-stimulated neutrophils were observed when DCFH oxidation assay was used. SNP increased, while SIN-1 decreased the fMLP-stimulated respiratory burst of neutrophils (Fig. 1). Figure 2 demonstrates that $30 \mathrm{~min}$ preincubation with both nitrovasodilators decreased the respiratory burst of PMA-stimulated and fMLP-stimulated neutrophils as it was measured with CL and DCFH oxidation assays. As shown in Fig. 3, the removal of SNP from the cells environment cancelled its down-regulating effect on the oxidative burst of

Table 1. Nitrite generation from NO donors in the presence of neutrophils and in the cell free system

\begin{tabular}{|c|c|c|c|c|c|c|c|}
\hline \multirow[t]{2}{*}{ Incubation (min) } & \multicolumn{2}{|c|}{ SNP (cell fee system) } & \multicolumn{2}{|c|}{ SIN-1 (cell fee system) } & \multicolumn{3}{|c|}{ Spermine NONOate (cell fee system) } \\
\hline & $1000 \mu \mathrm{M}$ & $100 \mu \mathrm{M}$ & $1000 \mu \mathrm{M}$ & $100 \mu \mathrm{M}$ & $1000 \mu \mathrm{M}$ & $100 \mu \mathrm{M}$ & $10 \mu \mathrm{M}$ \\
\hline \multirow[t]{3}{*}{$\begin{array}{l}30 \\
60\end{array}$} & $\begin{array}{l}1.2 \pm 0.6 \\
2.3 \pm 0.4\end{array}$ & $\begin{array}{l}0.1 \pm 0.1 \\
0.7 \pm 0.4\end{array}$ & $\begin{array}{r}48.4 \pm 15.3 \\
187 \pm 20.3\end{array}$ & $\begin{array}{r}9.4 \pm 3.1 \\
13.8 \pm 2.5\end{array}$ & $\begin{array}{l}288.1 \pm 32.2 \\
288.0 \pm 10.1\end{array}$ & $\begin{array}{l}137.8 \pm 3.1 \\
125.2 \pm 7.9\end{array}$ & $\begin{array}{l}15.5 \pm 0.5 \\
13.3 \pm 1.6\end{array}$ \\
\hline & \multicolumn{2}{|c|}{ SNP+neutrophils } & \multicolumn{2}{|c|}{ SIN-1+neutrophils } & \multicolumn{3}{|c|}{ Spermine NONOate + neutrophils } \\
\hline & $1000 \mu \mathrm{M}$ & $100 \mu \mathrm{M}$ & $1000 \mu \mathrm{M}$ & $100 \mu \mathrm{M}$ & $1000 \mu \mathrm{M}$ & $100 \mu \mathrm{M}$ & $10 \mu \mathrm{M}$ \\
\hline $\begin{array}{l}30 \\
60\end{array}$ & $\begin{array}{r}4.2 \pm 1.2 \\
12.3 \pm 1.7\end{array}$ & $\begin{array}{l}1.2 \pm 0.8 \\
2.0 \pm 0.9\end{array}$ & $\begin{array}{c}36.1 \pm 8.7 \\
104.3 \pm 12.7\end{array}$ & $\begin{array}{r}4.1 \pm 0.8 \\
19.3 \pm 9.6\end{array}$ & $\begin{array}{l}308.0 \pm 16.9 \\
300.9 \pm 11.9\end{array}$ & $\begin{array}{l}132.2 \pm 12.2 \\
118.5 \pm 9.4\end{array}$ & $\begin{array}{l}13.7 \pm 7.8 \\
12.0 \pm 1.2\end{array}$ \\
\hline
\end{tabular}

SNP $(100 \mu \mathrm{M}$ and $1000 \mu \mathrm{M})$ or SIN-1 $(100 \mu \mathrm{M}$ and $1000 \mu \mathrm{M})$ or spermine NONOate $(10-1000 \mu \mathrm{M})$ were added to HBSS (cell free system) or to neutrophils $\left(1 \times 10^{5}\right.$ cells) in $\mathrm{HBSS}$ for 30 or $60 \mathrm{~min}$ at $37^{\circ} \mathrm{C}$ with $5 \% \mathrm{CO}_{2}$. The generation of nitrite from NO donors was measured using Griess reagents. Data are expressed as mean \pm standard deviation of three independent experiments. 
Chemiluminescence assay
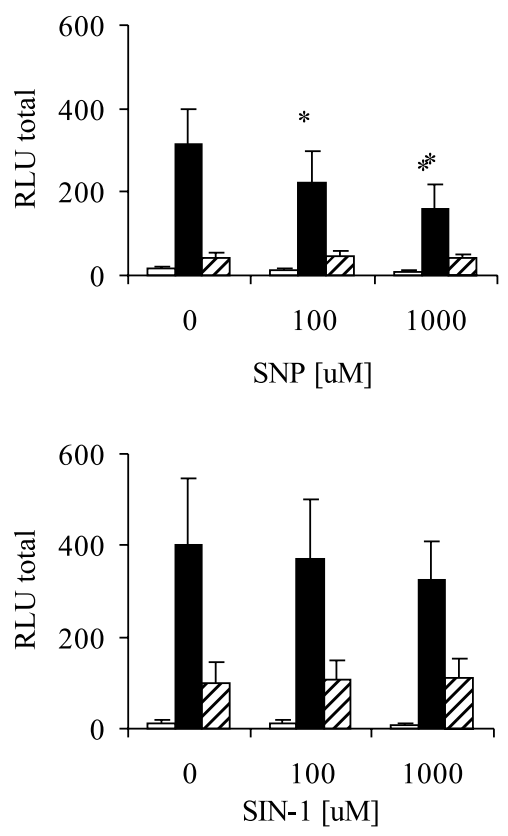

DCFH oxidation assay
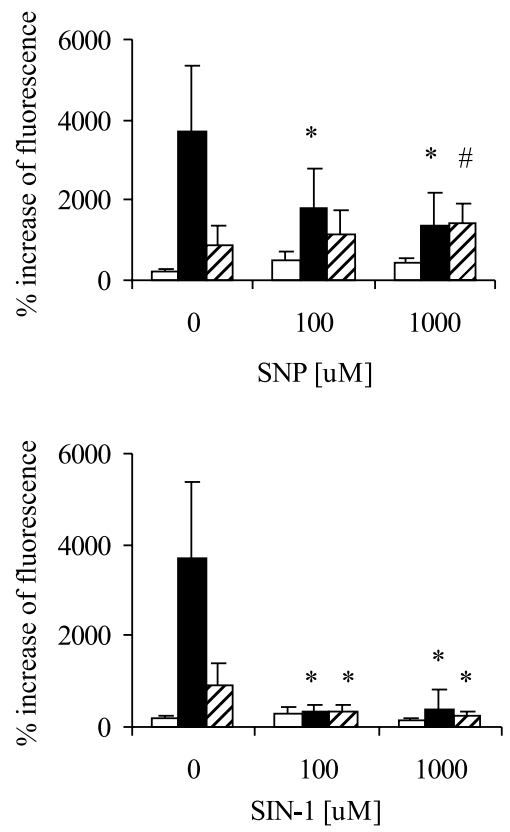

FIG. 1. Effect of brief pre-treatment with nitrovasodilators on the respiratory burst of stimulated neutrophils in vitro. Neutrophils $\left(1 \times 10^{5}\right.$ cells) were untreated or pre-treated with nitrovasodilators at the concentrations of $100 \mu \mathrm{M}$ and $1000 \mu \mathrm{M}$ for 1-2 min, and then stimulated with PMA (closed bars) or with fMLP (hatched bars) or were unstimulated (open bars). See details in Materials and methods. Data are expressed as means of RLU total or per cent increase of fluorescence \pm standard deviation of six independent experiments carried out with neutrophils from different individuals. * Statistically significant decrease: neutrophils versus neutrophils with nitrovasodilators $(p \leq 0.02) .{ }^{\#}$ Statistically significant increase: neutrophils versus neutrophils with SNP $(p \leq 0.02)$.

Chemiluminescence assay
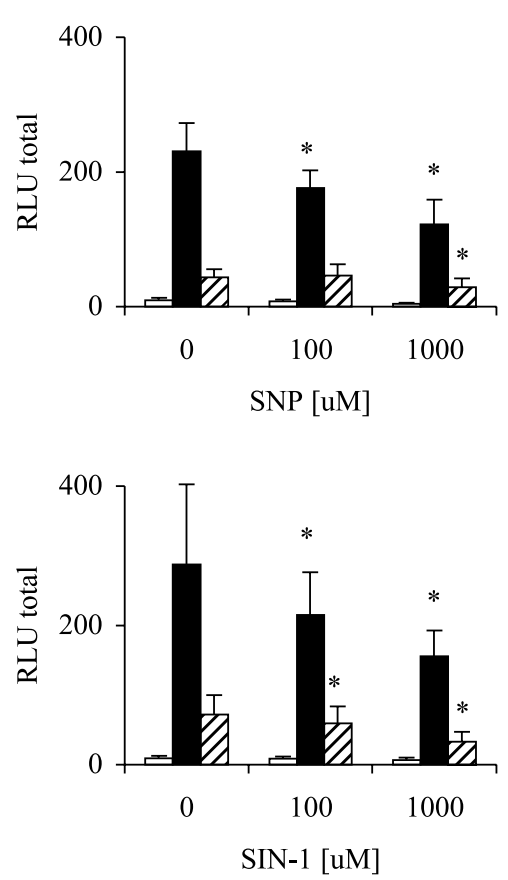

DCFH oxidation assay
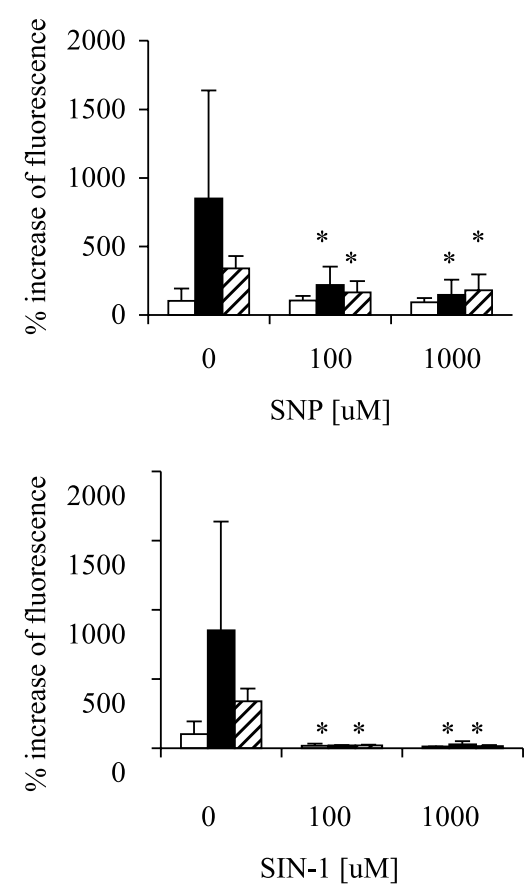

FIG. 2. Effect of $30 \mathrm{~min}$ pre-treatment with nitrovasodilators on the respiratory burst of activated neutrophils in vitro. Neutrophils $\left(1 \times 10^{5}\right.$ cells $)$ were untreated or pre-treated with nitrovasodilators at the concentrations of $100 \mu \mathrm{M}$ and $1000 \mu \mathrm{M}$ for 30 min and then stimulated with PMA (closed bars) or with fMLP (hatched bars) or were unstimulated (open bars). See details in Materials and methods. Data are expressed as means of RLU total or per cent increase of fluorescence \pm standard deviation of six independent experiments carried out with neutrophils from different individuals. * Statistically significant decrease: neutrophils versus neutrophils with nitrovasodilators $(p \leq 0.02)$. 
Chemiluminescence assay
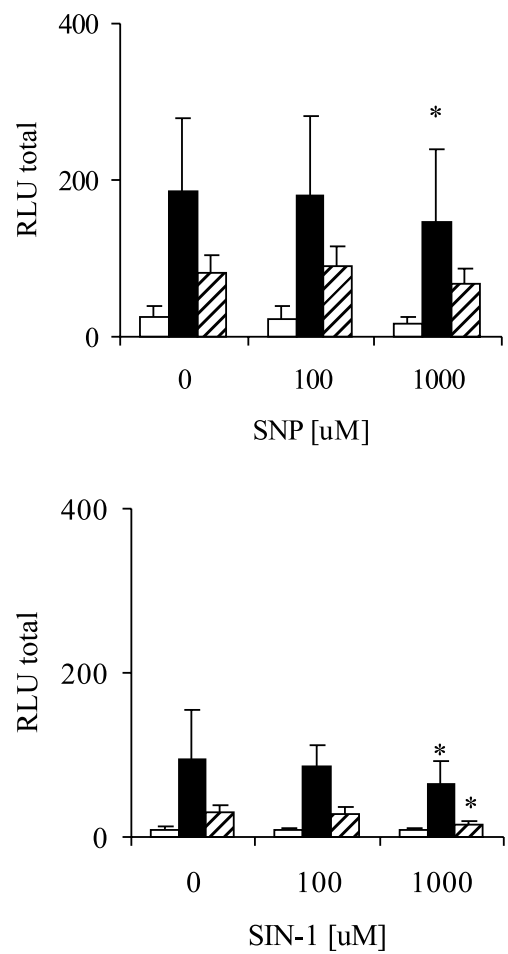

DCFH oxidation assay
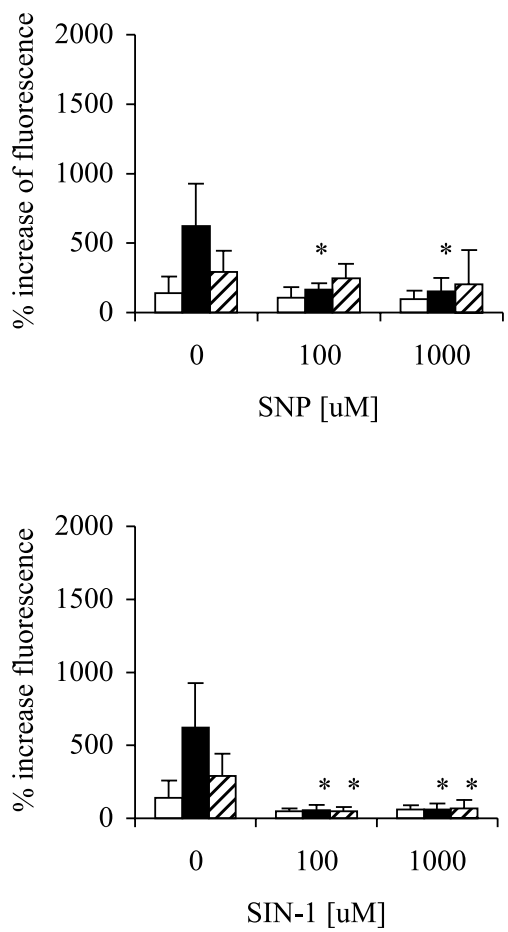

FIG. 3. Effect of withdrawal of nitrovasodilators from neutrophil environment prior to stimulation of cells to respiratory burst in vitro. Neutrophils $\left(1 \times 10^{5}\right.$ cells) were untreated or pre-treated with nitrovasodilators at the concentrations of $100 \mu \mathrm{M}$ and $1000 \mu \mathrm{M}$ for $30 \mathrm{~min}$, washed to remove SNP and SIN-1, and then stimulated with PMA (closed bars) or with fMLP (hatched bars) or were unstimulated (open bars). See details in Materials and methods. Data are expressed as means of RLU total or per cent increase of fluorescence \pm standard deviation of six independent experiments carried out with neutrophils from different individuals. * Statistically significant decrease: neutrophils versus neutrophils with nitrovasodilators $(p \leq 0.02)$.

fMLP-stimulated but not PMA-stimulated neutrophils, whereas the inhibitory effects of SIN-1 were not reversed after its withdrawal.

Data presented in Fig. 4 demonstrate that 1-2 min pre-incubation with spermine NONOate decreased the respiratory burst of PMA-stimulated but not of fMLP-stimulated neutrophils. Thirty minutes' pre-

\section{$1-2 \mathrm{~min}$}

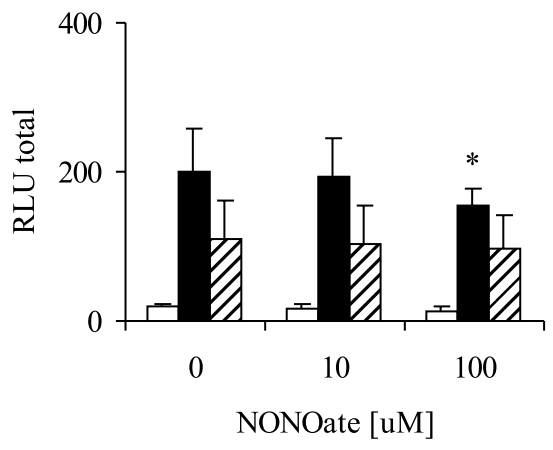

incubation with this $\mathrm{NO}$ donor decreased the oxidative burst of PMA-activated and fMLP-activated cells. It was not possible to perform experiments with NONOate at concentrations higher than $100 \mu \mathrm{M}$ because that caused cell damage.

It should be stressed that both nitrovasodilators at the concentrations used did not interfere with lumi-

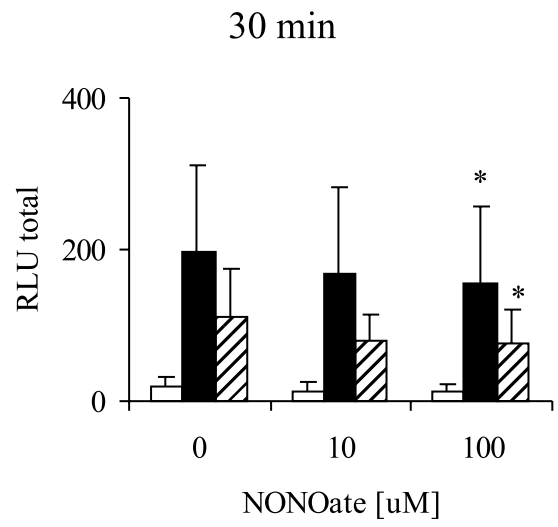

FIG. 4. Effect of NONOate on the respiratory burst of stimulated neutrophils in vitro. Neutrophils $\left(1 \times 10^{5}\right.$ cells $)$ were untreated or pre-treated with NONOate at the concentrations of $10 \mu \mathrm{M}$ and $100 \mu \mathrm{M}$ for 1-2 min or 30 min, and then stimulated with PMA (closed bars) or with fMLP (hatched bars) or were unstimulated (open bars). See details in Materials and methods. Data are expressed as means of RLU total \pm standard deviation of six independent experiments carried out with neutrophils from different individuals. * Statistically significant decrease: neutrophils versus neutrophils with nitrovasodilators $(p \leq 0.02)$. 
nol or DCFH diacetate and did not produce any signal in the cell free system as was verified in both assays.

\section{Involvement of PKC and PKT pathways in the NO donor-mediated decrease of respiratory burst of activated neutrophils}

We examined the effect of blocking the PKC or PKT activity on the nitrovasodilator-mediated decrease of respiratory burst of stimulated neutrophils. As shown in Fig. 5, PKC inhibitors (H-7 and NPC) at the used doses had no effect on fMLP-induced neutrophil oxidative burst, but when added prior to the induction of this process by PMA they caused a significant reduction of it. These data indicate that fMLP activates neutrophils' oxidative metabolism through the PKCindependent mechanism. PKT inhibitors (genistein and herbimicin A) caused a significant reduction of respiratory burst of PMA-stimulated and fMLP-stimulated neutrophils (Fig. 5). These results indicate that PKT participates in the induction of PMA-activated neutrophils' respiratory burst. Data presented in Fig. 6 demonstrate that $\mathrm{PKC}$ inhibitor $\mathrm{H}-7$, administered prior to the addition of SNP and PMA or fMLP, partially but significantly diminished the inhibitory effect of the NO donor, whereas H-7 did not affect the action of SIN-1. The similar results we observed with NPC (data not shown). As shown in Fig. 7, the PKT inhibitor genistein did not affect the inhibitory effect of SNP. However, genistein attenuated the inhibitory effect of SIN-1 on fMLP-stimulated but not on PMAstimulated neutrophils. Similar results were observed with herbimicin A (data not shown).

Genistein did not affect the inhibitory effect of spermine NONOate but $\mathrm{H}-7$ significantly diminished the inhibitory effect of spermine NONOate on respiratory burst of activated neutrophils. The percentage of inhibition was as follow: neutrophils + NONOate + fMLP, $22.2 \pm 11.2$ versus neutrophils $+\mathrm{H}$ $7+$ NONOate + fMLP,$\quad 10.7 \pm 9.4 \quad(p \leq 0.05, \quad n=5)$; neutrophils + NONOate + PMA, $23.9 \pm 11.4$ versus neutrophils + H-7 + NONOate + PMA, $15 \pm 7.2(p \leq$ $0.05, n=5)$.

\section{Adhesive activity of nitrovasodilator-treated neutrophils}

TNF- $\alpha$ enhanced the adhesion of neutrophils after 30 min of incubation with cells (from optical density $(O D)=0.070 \pm 0.029$ in the control sample up to $\mathrm{OD}=0.130 \pm 0.052$ in the presence of cytokine; $p \leq$ $0.04, n=5)$. The data in Table 2 demonstrate the different effect of SNP and SIN-1 on the neutrophil
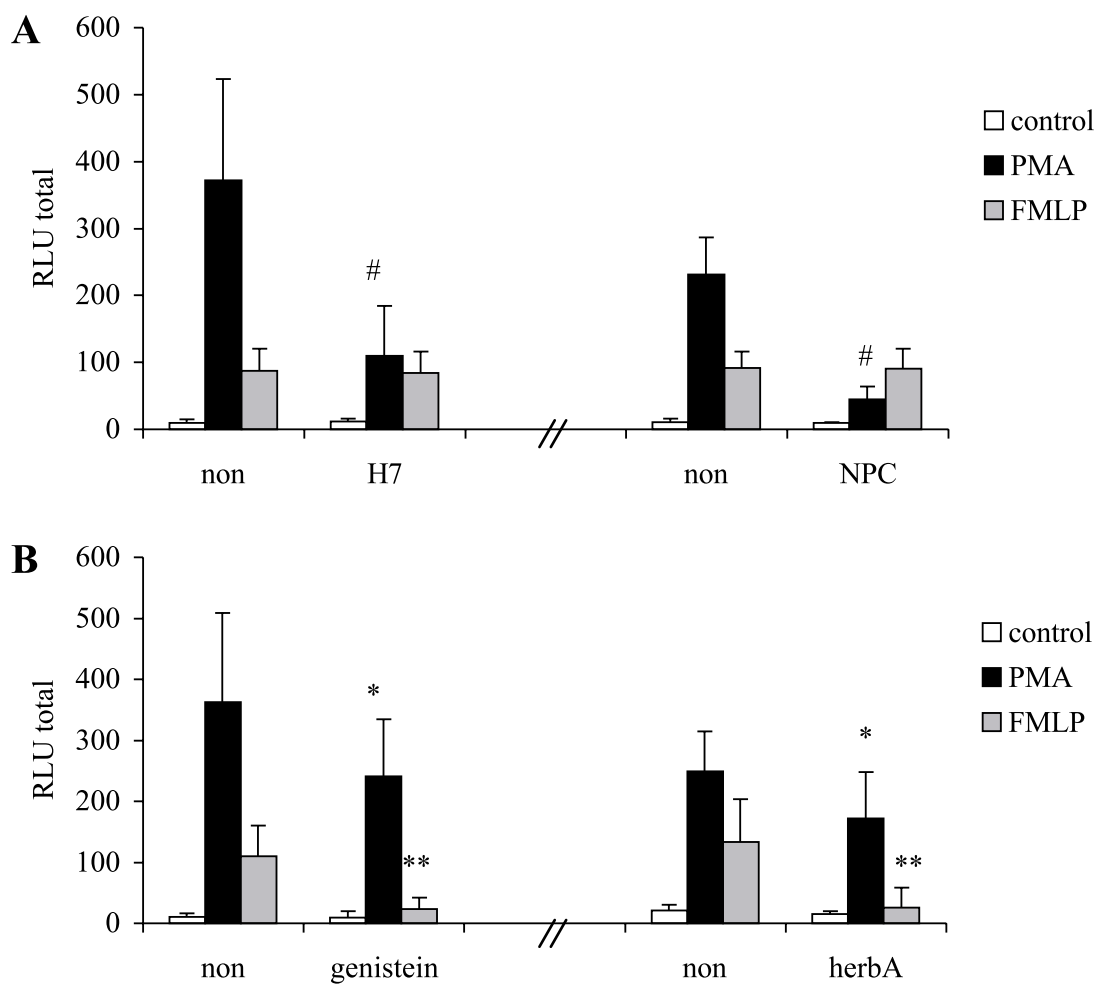

FIG. 5. Effects of PKC (A) and PKT (B) inhibitors on PMA-induced and fMLP-induced respiratory burst of neutrophils. Neutrophils $\left(1 \times 10^{5}\right)$ were first treated with $\mathrm{H}-7(100 \mu \mathrm{M})$ or NPC $(1 \mu \mathrm{M})(\mathrm{A})$ or with genistein $(10 \mu \mathrm{M})$ or herbimicin $\mathrm{A}(1 \mu \mathrm{M})(\mathrm{B})$ for $15 \mathrm{~min}$. Then, the cells were stimulated with $0.1 \mu \mathrm{g} / \mathrm{ml}$ of PMA or $10^{-6} \mathrm{M} \mathrm{fMLP}$, respectively. The CL reading was recorded for $30 \mathrm{~min}$ at $2 \mathrm{~min}$ intervals. The data are expressed as the area under the obtained curve of CL versus time (RLU total). Data are the means \pm standard deviation of six independent experiments carried out with neutrophils from different individuals. Statistical significance: " PMA versus PMA+PKC inhibitors, $p \leq 0.02 ;$ * PMA versus PMA+PKT inhibitors, $p \leq 0.02 ; * *$ fMLP versus fMLP + PKT inhibitors, $p \leq 0.02$. 

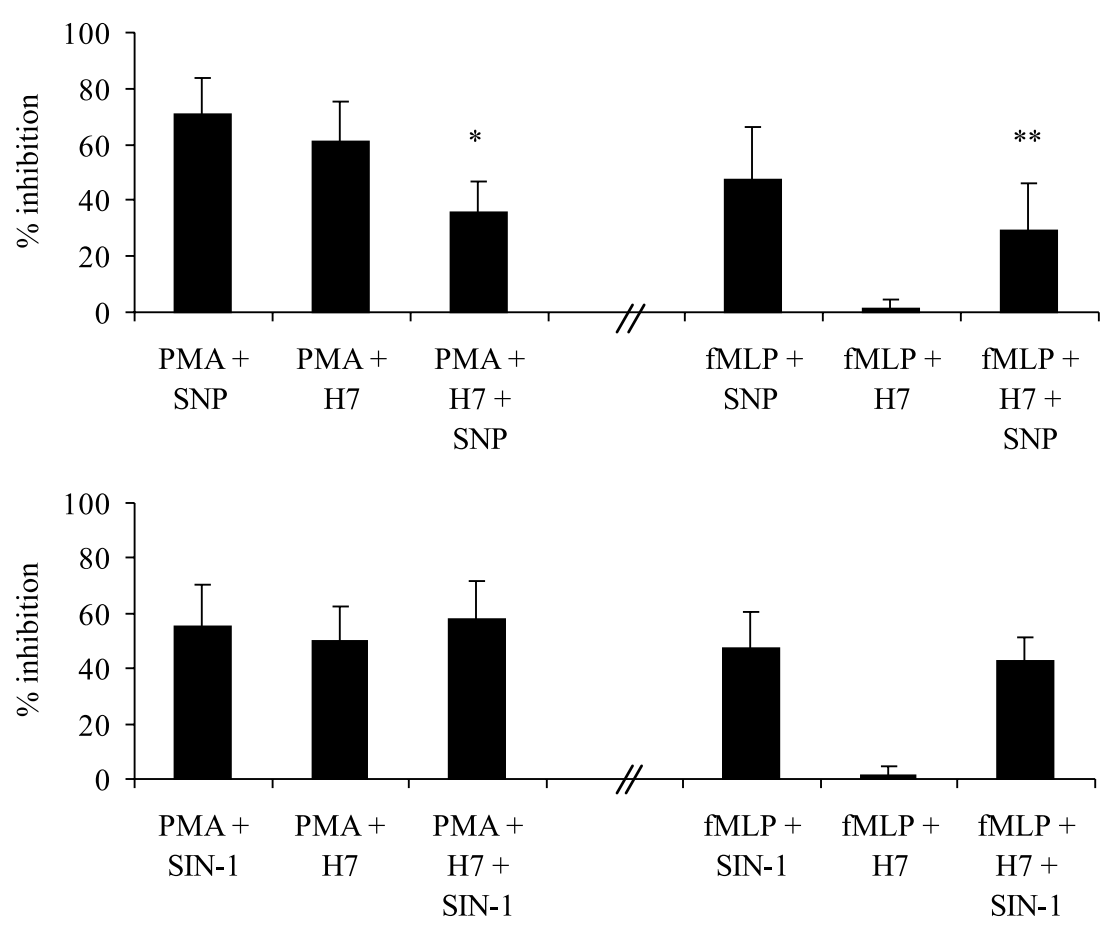

FIG. 6. Effect of PKC inhibitor on the SNP-mediated and SIN-1-mediated oxidative burst of activated neutrophils. Neutrophils $\left(1 \times 10^{5}\right)$ were first treated with $\mathrm{H}-7(100 \mu \mathrm{M})$ for $15 \mathrm{~min}$. Then, the cells were incubated with $1000 \mu \mathrm{M}$ of SNP or $1000 \mu \mathrm{M}$ of SIN-1 for $30 \mathrm{~min}$ and next stimulated with $0.1 \mu \mathrm{g} / \mathrm{ml}$ of PMA or $10^{-6} \mathrm{M}$ of fMLP. The CL reading was recorded for $30 \mathrm{~min}$ at 2 min intervals. The data are expressed as means of per cent inhibition of respiratory burst \pm standard deviation of six independent experiments carried out with neutrophils from different individuals. Statistical significance: * SNP +PMA versus $\mathrm{SNP}+\mathrm{PMA}+\mathrm{H}-7, p \leq 0.02 ; * * \mathrm{SNP}+\mathrm{fMLP}$ versus SNP $+\mathrm{fMLP}+\mathrm{H}-7, p \leq 0.02$.
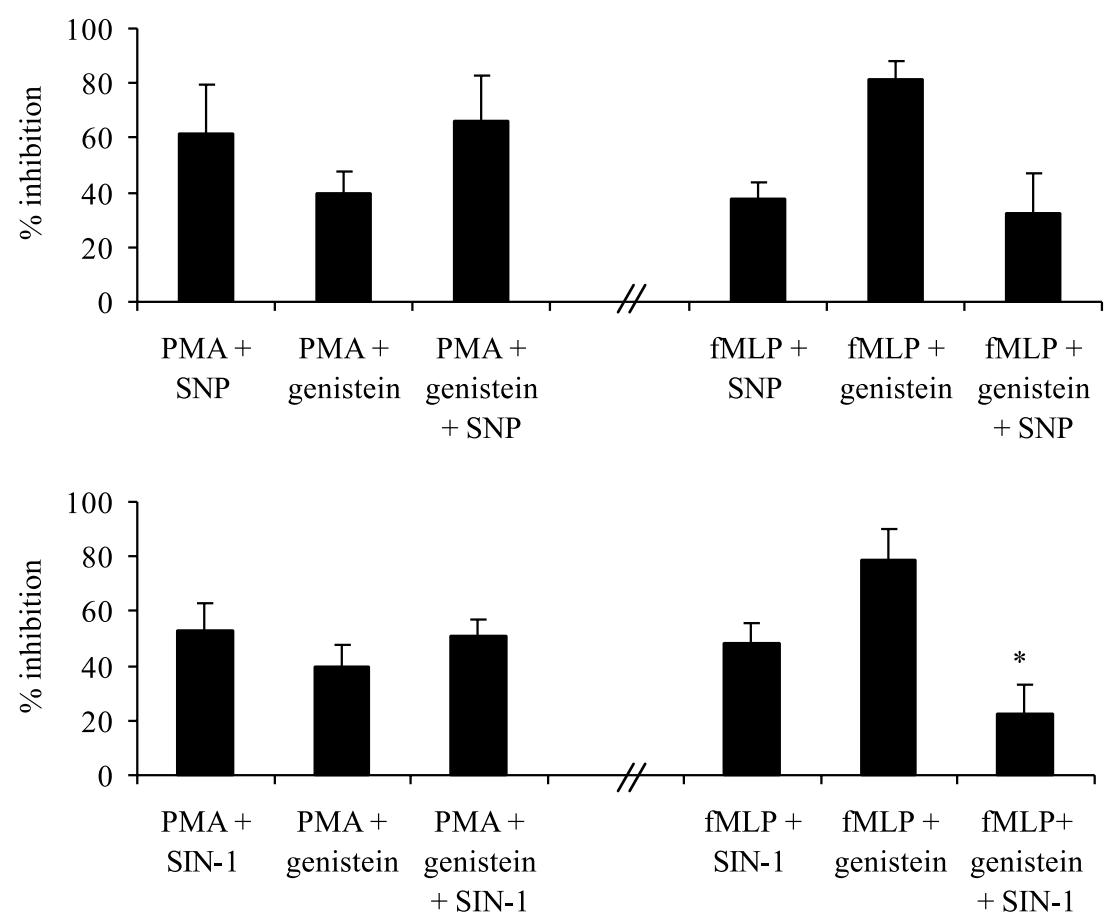

FIG. 7. Effect of PKT inhibitor on the SNP-mediated and SIN-1-mediated oxidative burst of activated neutrophils. Neutrophils $\left(1 \times 10^{5}\right)$ were first treated with genistein $(10 \mu \mathrm{M})$ for $15 \mathrm{~min}$. Then, the cells were incubated with $1000 \mu \mathrm{M}$ of SNP or $1000 \mu \mathrm{M}$ of SIN-1 for 30 min and next stimulated with $0.1 \mu \mathrm{g} / \mathrm{ml}$ of PMA or $10^{-6} \mathrm{M}$ of fMLP. The CL reading was recorded for $30 \mathrm{~min}$ at 2 $\mathrm{min}$ intervals. The data are expressed as means of per cent inhibition of respiratory burst \pm standard deviation of six independent experiments carried out with neutrophils from different individuals. Statistical significance: * SIN-1+fMLP versus $\mathrm{SIN}-1+\mathrm{fMLP}+$ genistein, $p \leq 0.02$. 
Table 2. Effect of nitrovasodilators on the adhesive activity of neutrophils

\begin{tabular}{lcccccc}
\hline Time $(\mathrm{min})$ & \multicolumn{3}{c}{ OD $(560 \mathrm{~nm}$ and $630 \mathrm{~nm})$} \\
\cline { 2 - 4 } & Control & \multicolumn{2}{c}{ SNP } & & \multicolumn{2}{c}{ SIN-1 } \\
\cline { 2 - 4 } \cline { 5 - 7 } & & $100 \mu \mathrm{M}$ & $1000 \mu \mathrm{M}$ & & $100 \mu \mathrm{M}$ & $1000 \mu \mathrm{M}$ \\
\hline 30 & $0.070 \pm 0.023$ & $0.068 \pm 0.010$ & $0.075 \pm 0.018$ & & $0.064 \pm 0.019$ & $0.051 \pm 0.019^{*}$ \\
60 & $0.258 \pm 0.039$ & $0.215 \pm 0.043$ & $0.260 \pm 0.043$ & & $0.207 \pm 0.027^{*}$ & $0.189 \pm 0.049^{*}$ \\
\hline
\end{tabular}

Neutrophils $\left(1 \times 10^{6}\right.$ cells) were distributed into 24 -well plates and were incubated without or with nitrovasodilators (100 $\mu \mathrm{M}$ or $\left.1000 \mu \mathrm{M}\right)$ for 30 and $60 \mathrm{~min}$ at $37^{\circ} \mathrm{C}$, with $5 \%$ of $\mathrm{CO}_{2}$. Non-adherent cells were removed, and adherent cells were exposed for MTT solution as described in Materials and methods. Data are expressed as means of optical densities \pm standard deviation of eight independent experiments carried out with neutrophils from different individuals. * Statistical significance: neutrophils versus neutrophils with SIN-1 ( $p \leq 0.05)$.

adhesion. Neutrophil adhesion was reduced after treatment of cells with $100 \mu \mathrm{M}$ of SIN-1 for 60 min and with $1000 \mu \mathrm{M}$ of SIN-1 for 30 and $60 \mathrm{~min}$. In contrast, SNP did not affect their adhesion to the plastic surface. Spermine NONOate did not influence on the adherence of neutrophils (data not shown).

\section{Discussion}

The mechanism of $\mathrm{NO}$ generation from SNP is controversial. Some authors have shown that NO could be spontaneously generated from SNP, ${ }^{13,21}$ but others have demonstrated that NO formation required the presence of vascular tissue ${ }^{12}$ and/or the visible light. ${ }^{22}$ We have shown here that SNP released NO in the cell free system; however, the presence of neutrophils enhanced its generation (Table 1). SIN-1, the metabolite of molsidomine, produced NO spontaneously without any cofactors. ${ }^{12-14}$

The results of our experiments are in accordance with observations of others ${ }^{21-24}$ that SNP and SIN-1 at concentrations above $50 \mu \mathrm{M}$ decrease the reactive oxygen species production by neutrophils. However, it should be also emphasized that biological effects of SNP and SIN-1 strongly depended on the treatment time of neutrophils and on the stimulus employed to activate the cells. Our data indicate that SNP and SIN1 should act on neutrophils for longer than 1-2 min to exert their modulatory effects, when the receptordependent activator is used (Figs. 1 and 2). We may speculate that the different oxidative response of short-time nitrovasodilator pre-treated neutrophils arise from different kinetics of the respiratory burst induced by PMA and by fMLP. The kinetics of CL responses show that the peak of the PMA-induced oxidative response occurs $10-15$ min after activation of cells while the peak of the fMLP-induced respiratory burst of neutrophils occurs 1-5 min after neutrophil activation. ${ }^{23}$ Our results and those of others ${ }^{21}$ suggest that SNP and SIN-1 may affect the respiratory burst of neutrophils by various signalling pathways (Fig. 3). The inhibition of the PMA-dependent respiratory burst of neutrophils by SNP and SIN1 indicates that NO donors exert effects independent of G-proteins. However, SIN-1 can also exert some effect via or close to G-proteins since it decreased the fMLP-mediated neutrophils' oxidative burst. ${ }^{25}$

In the course of NADPH oxidase activation distinct signal transduction pathways can be activated. ${ }^{4,7,11}$ The signal transduction through receptors with tyrosine kinase activity occurs upon interaction of fMLP with its receptor; however, the other signalling pathway involves PKC via activation of phospholipase C. PMA directly activates PKC, and indirectly PKT. ${ }^{11,26}$ The role of protein kinases in the action of $\mathrm{NO}$ donors on the respiratory burst of neutrophils is not clear and it was not examined intensively. In this paper we show that SNP action is mainly associated with PKC, while SIN-1 is associated with PKT activity (Figs. 6 and 7). We suppose that the influence of NO donors on PKC, PKT and/or G-protein activities can be responsible for the decrease of respiratory burst of activated neutrophils.

It was demonstrated by others that the effect of SNP and SIN-1 on the neutrophil functions was mediated by $\mathrm{NO} .^{21,23,24}$ Our results suggest that NO donors can also affect neutrophils in the NO-independent pathway. Feelisch ${ }^{13}$ maintained that a relatively small amount of NO released from SNP in vitro was not sufficient for activating soluble guanylate cyclase and that biological effects of SNP were largely independent of NO. It was also suggested that SNP might mediate effects by a NO-dependent and soluble guanylate cyclase-independent mechanism. ${ }^{14}$ It should be also considered that during decomposition of SNP a cyanide is released. However, Forslund and Sundqvist ${ }^{23}$ demonstrated that the effect of SNP on the respiratory burst of neutrophils was mediated by NO not by cyanide. Our data show that SNP, similar to spermine NONOate, decreases PMA-induced respiratory burst of neutrophils and affects the PKC activity. It can suggest that the action of SNP may depend on NO. Spontaneous decomposition of SIN-1 leads to the generation of equimolar quantities of $\mathrm{NO}$ and $\mathrm{O}_{2}^{-}$, which interact almost instantly to produce peroxynitrite anion $\left(\mathrm{ONOO}^{-}\right){ }^{12}$ However, it should be emphasized that formation of $\mathrm{ONOO}^{-}$during decomposition of SIN-1 in vitro strongly depends on the oxygen concentration in the reaction mixture. ${ }^{27,28}$ 
Our data show that the SIN-1 biological effect on some neutrophils' activity is different from both spermine NONOate and SNP, and mainly depends on $\mathrm{ONOO}^{-}$, while SNP action is mediated by NO.

ACKNOWLEDGEMENTS. This research was supported by grant 4 P05A 034 18 from The State Committee for Scientific Research (KBN) Poland.

\section{References}

1. Siminiak T, Ozawa T. Neutrophil mediated myocardial injury. Int J Biochem 1993; 25: 147-156.

2. Hansen PR. Role of neutrophils in myocardial ischemia and reperfusion. Circulation 1995; 91: 1872-1885.

3. Baxter GF. The neutrophil as a mediator of myocardial ischemiareperfusion injury: time to move on. Basic Res Cardiol 2002; 97: 268 275 .

4. Babior BM. NADPH oxidase: an update. Blood 1999; 93: 1464-1476.

5. Jones RD, Hancock JT, Morice AH. NADPH oxidase: a universal oxygen sensor? Free Radic Biol Med 2000; 29: 416-424.

6. Dang PMC, Fontayne A, Hakim J, El-Benna J, Perianin A. Protein kinase

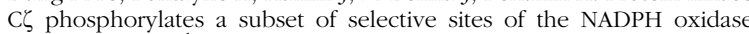
component $\mathrm{p} 47^{\text {phox }}$ and participates in formyl peptide-mediated neutrophil respiratory burst. J Immunol 2001; 166: 1206-1213.

7. Reeves EP, Dekker LV, Forbes LV, Wientjes FB, Grogan A, Pappin DC, Segal AW. Direct interaction between $\mathrm{p} 47^{\text {phox }}$ and protein kinase $\mathrm{C}$ evidence for targeting of protein kinase $\mathrm{C}$ by $\mathrm{p} 47^{\mathrm{phox}}$ in neutrophils. Biochem J 1999; 344: 859-866.

8. Karlson A, Nixin JB, McPhail LC. Phorbol myristate acetate induces neutrophil NADPH-oxidase activity by two separate signal transduction pathways: dependent or independent of phosphatidylinositol 3-kinase. $J$ Leukoc Biol 2000; 67: 396-404

9. Watson F, Robinson J, Edwards SW. Protein kinase C-dependent and independent activation of the NADPH oxidase of human neutrophils. $J$ Biol Chem 1991: 266. 7432-7439.

10. Dewas CD, Fay M, Gougerot-Pocidalo MA, El-Benna J. The mitogenactivated protein kinase extracellular signal-regulated kinase $1 / 2$ pathway is involved in formyl-methionyl-leucyl-phenylalanine-induced p $47^{\text {phox }}$ phosphorylation in human neutropohils. J Immunol 2000; 165: $5238-5244$

11. Worthen GS, Avdi N, Buhl AM, Suzuki N, Johnson GL. fMLP activates Ras and Raf in human neutrophils. Potential role in activation of MAP kinase. J Clin Invest 1994; 94: 815-823.

12. Yamamoto T, Bing RJ. Nitric oxide donors. Proc Soc Exp Biol Med 2000; 225: $200-206$

13. Feelisch MJ. The biochemical pathways of nitric oxide formation from nitrovasodilators: appropriate choice of exogenous NO donors and aspects of preparation and handling of aqueous NO solutions. $J$ Cardiovasc Pharmacol 1991; 17(Suppl 3): S25-S33.
14. Megson IL. Nitric oxide donor drugs. Drugs 2000; 25: 701-715.

15. Armstrong R. The physiological role and pharmacological potential of nitric oxide in neutrophils activation. Int Immunopharmacol 2001; 1: $1501-1512$

16. Klink M, Cedzynski M, Swierzko Ast, Tchorzewski H, Sulowska Z Involvement of nitric oxide donor compounds in the bactericidal activity of human neutrophils in vitro.J Med Mocrobiol 2003; 52: 303-308.

17. Dahlgren C, Karlsson A. Respiratory burst in human neutrophils. $J$ Immunol Methods 1999; 232: 3-14.

18. DeLeo FR, Allen LH, Apicella M, Nauseef WM. NADPH oxidase activation assembly during phagocytosis. J Immunol 1999; 163: $6732-6740$

19. Wang H, Joseph JA. Quantifying cellular oxidative stress by dichlorofluorescein assay using microplate reader. Free Radic Biol Med 1991; 27: $612-616$

20. Oez S, Weltre K, Platzer E, Kalden JR. A simple assay for quantifying the inducible adherence of neutrophils. Immunobiology 1990; 180: $308-$ 315.

21. Forslund T, Sundqvist T. Nitric oxide regulates the chemiluminescence from stimulated human neutrophils. APMIS 1995; 103: 813-817.

22. Bates JN, Baker MT, Guerra R Jr, Harrison DG. Nitric oxide generation from nitroprusside by vascular tissue. Evidence that reduction ot the nitroprusside anion and cyanide loss are required. Biochem Pharmacol 1991; 42: S157-S165.

23. Forslund T, Sundqvist T. Nitric oxide reduces hydrogen peroxide production from human polymorphonuclear neutrophils. Eur J Clin Invest 1995; 25: 9-14

24. Pieper GM, Clarke GA, Gross GJ. Stimulatory and inhibitory action of nitric oxide donor agents vs. nitrovasodilators on reactive oxygen production by isolated polymorphonuclear leukocytes. $J$ Pharmacol Exp Ther 1994; 269: 451-456.

25. Clancy RM, Leszczynska-Piziak J, Abramson SB. Nitric oxide, an endothelial cell relaxation factor, inhibits neutrophil superoxide anion production via a direct action on the NADPH oxidase. J Clin Invest 1992 90: $1116-1121$

26. Ptasznik A, Prossnitz ER, Yoshikawa D, Smrcka A, Traynor-Kaplan AE, Bokoch GM. A tyrosine kinase signaling pathway accounts for the majority of phosphatidylinositol 3,4,5-triphosphate formation in chemoattractant-stimulated human neutrophils. J Biol Chem 1996; 271 $25204-25207$

27. Brunelli L, Crow JP, Beckman JS. The comparative toxicity of nitric oxide and peroxynitrite to Escherichia coli. Arch Biochem Biophys 1995; 316 $327-334$.

28. Doulias PT, Barbouti A, Galaris D, Ischiropoulos H. SIN-1 induced DNA damage in isolated human peripheral blood lymphocytes as assessed by single cell gel electrophoresis (comet assay). Free Radic Biol Med 2001; 30: $679-685$.

\section{Received 18 July 2003}

Accepted 29 September 2003 


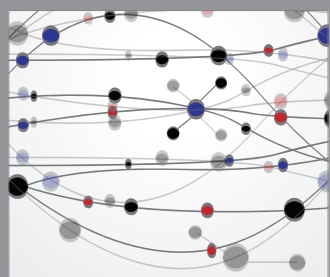

The Scientific World Journal
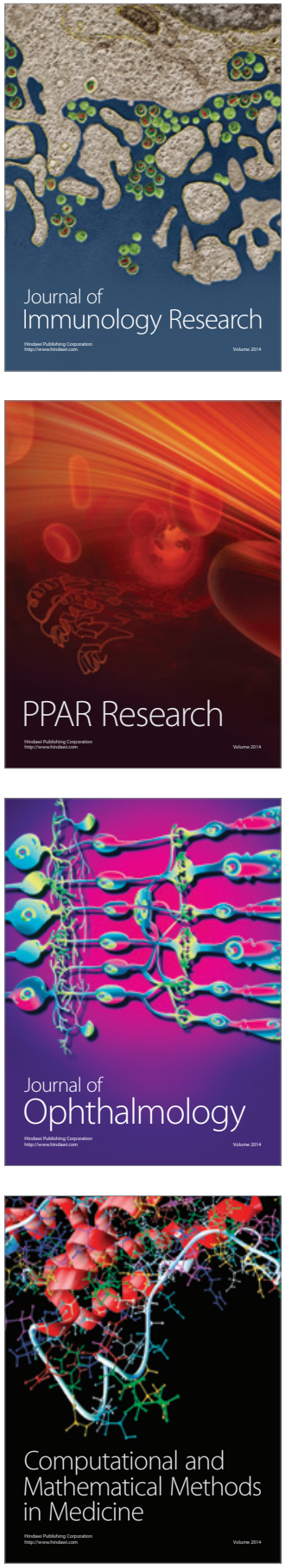

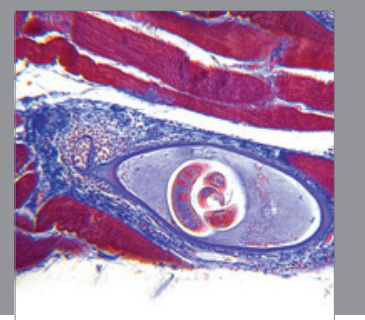

Gastroenterology

Research and Practice
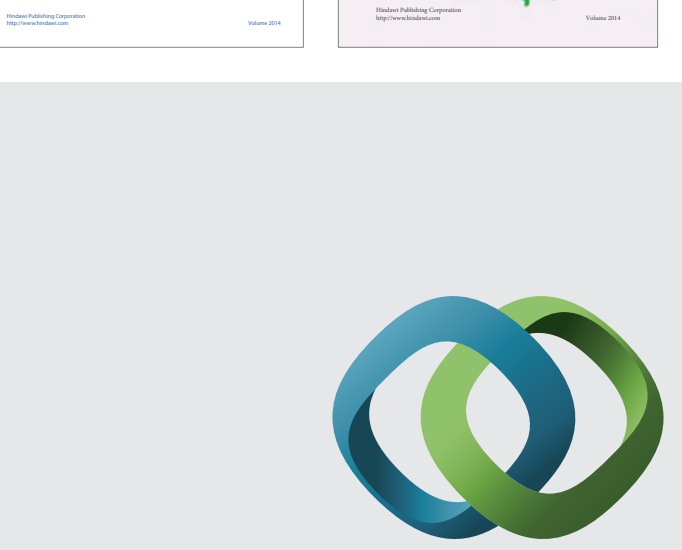

\section{Hindawi}

Submit your manuscripts at

http://www.hindawi.com
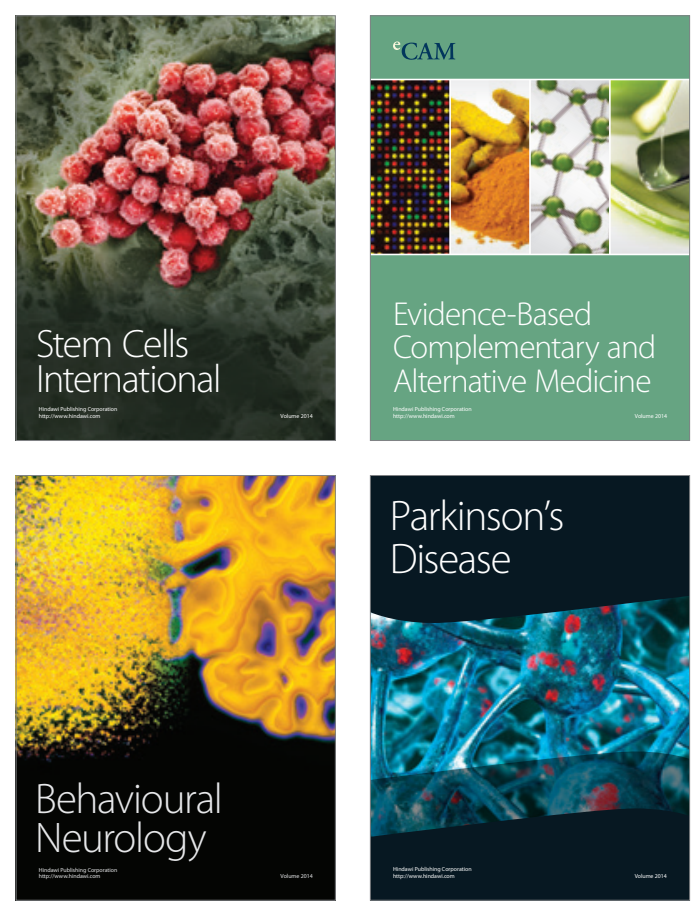

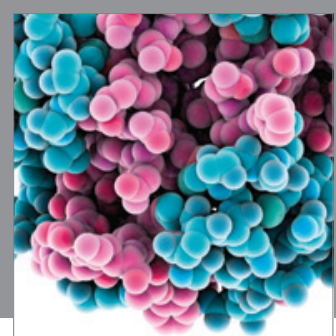

Journal of
Diabetes Research

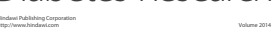

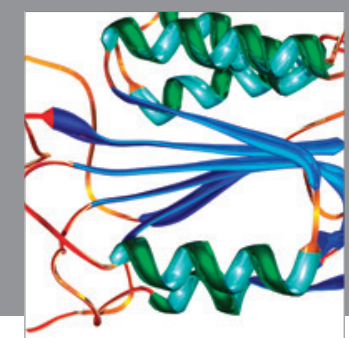

Disease Markers
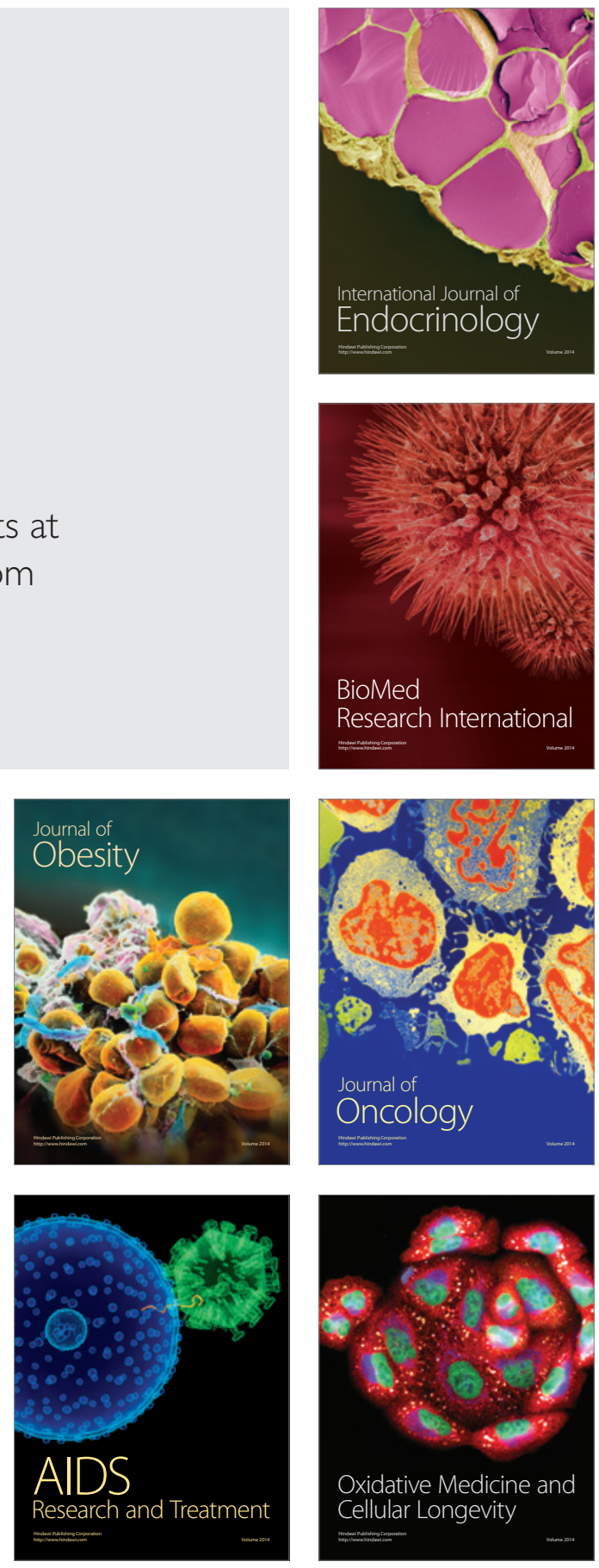